\title{
Correlation between Physical Fitness Components and Academic Achievement in Elementary School Students
}

\author{
Tisnasari Hafsah, ${ }^{1}$ Nurul Uyun, ${ }^{2}$ Reni Farenia ${ }^{3}$ \\ ${ }^{1}$ Department of Child Health Faculty of Medicine Universitas Padjadjaran/Dr. Hasan Sadikin \\ General Hospital Bandung, Indonesia, ${ }^{2}$ Faculty of Medicine Universitas Padjadjaran, Indonesia, \\ ${ }^{3}$ Department of Biomedical Sciences Faculty of Medicine Universitas Padjadjaran, Bandung, \\ Indonesia
}

\begin{abstract}
Background: Physical fitness is a degree of health status as a basic physical condition of someone to perform daily activity. Elementary school students should have a good physical fitness to obtain satisfactory academic achievement. The purpose of this study was to examine the correlation between physical fitness and academic achievement.

Methods: This study used an observational analytical method with cross-sectional design, conducted from September-October 2013, using total sampling method. There were 82 students of the 4th-6th-grade from Cikeruh 2 elementary school at Jatinangor. The school was chosen by random selection. The physical fitness assessment in this study consisted of step test to measure cardiorespiratory endurance, body mass index (BMI) for body composition, push-up for muscular strength and sit-up for muscular flexibility. Academic achievement was collected from the last examination result. Each component of physical fitness test results were converted to a score and then categorized.
\end{abstract}

Results: Most students (74.4\%) had fair physical fitness, boys 68.3\%, and girls $80.5 \%$. No correlation was found between physical fitness and academic achievement ( $\mathrm{p}=0.432$ and $\mathrm{r}=0.162$ ).

Conclusions: There is no significant correlation between physical fitness and academic achievement.

Keywords: Academic achievement, physical fitness, students

\section{Introduction}

Physical fitness is the degree of health status as a basic physical condition of someone to perform daily activity. ${ }^{1}$ There are some benefits for being physically fit, for example reduce the risk of metabolic syndrome and cardiovascular disease., ${ }^{2,3}$ Students should have good physical fitness in order to obtain a satisfactory academic achievement.

Many factors may affect academic achievement including genetic, school environment, school facilities, teacher competency, curriculum, and socioeconomic status, physical activity, nutritional status and special sense system for example visual acuity. ${ }^{4-8}$ Studies about physical fitness and academic achievement have been conducted previously, ${ }^{9-11}$ but was still rare in Indonesia. Particularly in Jatinangor district, there were no data on the study about physical fitness and academic achievement. As there are many schools in this district, which is still developing to become a modern society, physical fitness performance among students should be investigated whether it affects the academic achievement. Therefore, the purpose of this study was to examine the correlation between physical fitness and academic achievement.

\section{Methods}

This study was conducted from September to October 2012 at the Elementary School in Cikeruh in Jatinangor and used analytical method with cross-sectional design. The school was selected by simple random sampling, while subjects recruited in this study were students of $4^{\text {th }}-6^{\text {th }}$ grade. All procedures performed to the students was approved by the parents. and The approval for this study has been obtained from the Health Research Ethics Committee, Faculty of Medicine Universitas Padjadjaran.

Physical fitness measurement in this study

Correspondence: Tisnasari Hafsah, Department of Child Health Faculty of Medicine, Universitas Padjadjaran,/ Dr Hasan Sadikin General Hospital Jalan Pasteur No.38, Bandung, Indonesia, Email: tisnasari_hafsah@yahoo.com 
consisted of cardiorespiratory endurance, body composition and muscular fitness. Cardiovascular fitness was measured by step test. Body composition was measured by body mass index (BMI). Muscular flexibility was measured by sit-ups and muscular strength by push-ups.

Kash method of step test was taken within 3 minutes. After the test, the pulse rate was measured within 60 seconds. The BMI was collected from measurement of body weight and height. The muscular fitness test was measured by push-up and sit-up. The objective of this measurement is to do sit-ups and pushups as many as possible within 1 minute. Academic achievement was measured from the last examination result. Each component of physical fitness was categorized and converted to a score, then the score of physical fitness was correlated with the last examination result using the Spearman Pearson correlation method. Furthermore, data were analyzed using the Statistical Package for the Social Science (SPSS). P-value $<0.05$ was used for statistical significance.

\section{Results}

The total sample was 82 students, including
41 boys and 41 girls aged 10-12 years from the 4 th-- 6th-grade. From the characteristic of students at the Elementary School in Cikeruh in Jatinangor and the physical result, most students $(74.4 \%)$ had fair physical fitness, boys $68.3 \%$, and girls $80.5 \%$. The analysis result for correlation between physical fitness and academic achievement was $\mathrm{p}=0.432$ and $r=0.162$, which means that the correlation was not significant (Table 1 and Table 2).

\section{Discussion}

The result revealed that there was no significant correlation between physical fitness and academic achievement. This is contradictive with a previous study which states that there is correlation between physical fitness and academic achievement. ${ }^{9-10}$ The difference of method used in measuring the physical fitness and the academic achievement, sample size, and also characteristic and background of subject may influence this contradiction. In a meta-analysis by Álvarez-Bueno et al. ${ }^{11}$, physical education as a particular example of physical activity at school plays a positive role in academic achievement, specifically mathematics, reading, and composite scores among students. ${ }^{11}$ However, there were

Table 1 Characteristic of the students from Elementary School in Cikeruh in Jatinangor

\begin{tabular}{lccc}
\hline \multirow{2}{*}{ Characteristics } & Overall Sample & Boys & Girls \\
\cline { 2 - 4 } & $\mathrm{x} \pm \mathrm{SD}$ & $\mathrm{x} \pm \mathrm{SD}$ & $\mathrm{x} \pm \mathrm{SD}$ \\
\hline Age (years old) & $11.025 \pm 0.98$ & $11.15 \pm 0.99$ & $10.90 \pm 0.97$ \\
Weight $(\mathrm{kg})$ & $51.76 \pm 14.44$ & $34.55 \pm 7.52$ & $28.98 \pm 6.92$ \\
Height $(\mathrm{cm})$ & $140.22 \pm 7.29$ & $140.47 \pm 7.29$ & $139.96 \pm 7.29$ \\
Body mass index $\left(\mathrm{kg} / \mathrm{m}^{2}\right)$ & $13.91 \pm 3.97$ & $13.45 \pm 3.67$ & $14.38 \pm 4.25$ \\
Step test (beat/minute) & $128.33 \pm 17.80$ & $127.68 \pm 15.90$ & $128.98 \pm 19.69$ \\
Sit-up (times/minute) & $29.01 \pm 15.14$ & $38.78 \pm 15.40$ & $19.24 \pm 5.58$ \\
Physical fitness score & $12.5 \pm 2.09$ & $13.02 \pm 9.06$ & $11.9 \pm 2.13$ \\
Last examination result & $74.42 \pm 5.32$ & $74.04 \pm 5.31$ & $74.79 \pm 5.37$ \\
\hline
\end{tabular}

Note : $\mathrm{x}=$ mean, $\mathrm{SD}=$ standard deviation

Table 2 Physical Fitness Result of students at the Elementary School in Cikeruh in Jatinangor

\begin{tabular}{lccc}
\hline \multicolumn{1}{c}{ Category } & Boys n (\%) & Girls n (\%) & Total n (\%) \\
\hline Poor & $12(29.3)$ & $8(19.5)$ & $20(24.4)$ \\
Fair & $28(68.3)$ & $33(80.5)$ & $61(74.4)$ \\
Good & $1(2.4)$ & - & $1(1.2)$ \\
Total & $41(100)$ & $41(100)$ & $82(100)$ \\
\hline
\end{tabular}

Note : $n=$ number of sample 
limitations, including a variation of academic achievement measurement tools and lack of studies on the effect of physical activity interventions at after-school time.

This study did not observe other factors such as genetic, socioeconomic status, physical activity, nutritional status, special sense system for example visual, which could affect the academic achievement. ${ }^{4-8}$ Nutrition is important for children to reach their optimal physical and mental development. A study in Ethiopia ${ }^{12}$, where children with undernourishment were prevalent revealed the correlation between nutritional status and level of educational performance. Children with stunting, underweight and wasting showed low level of educational performance than normal children. Our study also noted about the possibility of nutritional status impaction. The average of body mass index (BMI) particularly for boys was $13.45 \pm 3.67$, which was less than -2 SD based on WHO Child growth reference 2007, while in the girl group was $14.38 \pm 4.25$ (less than -1 SD) ${ }^{13}$ Body mass index $<-2$ SD can be determined as moderate malnutrition (wasted) and BMI <-1 SD can be determined as mild malnutrition. This study also showed that low physical fitness was less prominent in the girl group than in boy's who impressed better physical fitness could be achieved if children had better nourishment, but correlation with academic performance was not yet explored. This was pointing out the limitation of the study.

In conclusion, there is no correlation between physical fitness and academic achievement. Therefore, further studies are needed to measure the association between academic achievement and related factors.

\section{References}

1. Giriwijoyo S. Ilmu faal olahraga: fungsi tubuh manusia pada olah raga. 1st ed. Bandung: FPOK UPI; 2007. p. 43.

2. LaMonte MJ, Barlow CE, Jurca R, Kampert JB, Church TS, Blair SN. Cardiorespiratory fitness is inversely associated with the incidence of metabolic syndrome. Circulation. 2005; 112 (4):505-12.

3. Gill JM, Malkova D. Physical activity, fitness and cardiovascular disease risk in adults: interactions with insulin resistance and obesity. Clin Sci (Lond).2006; 110(4):409-25.

4. Muhibin Syah ME. Psikologi pendidikan. 1st ed. Jakarta: Raja Grafinda Persada; 2003. p. 89.

5. Coe PW, Pivarnik JM, Womack CJ, Reeves MJ, Malina RM. Effect of physical education and activity levels on academic achievement in children. Med Sci Sports Exerc. 2006;38(8):1515-9.

6. Trudeau F, Shephard RJ. Physical education, school physical activity, school sports and academic perfomance. Int $\mathrm{J}$ Behav Nutr Phys Act. 2008;5(1):10-22.

7. Sabia JJ. The effect of body weight on adolescent academic perfomance. Southern Economic Journal. 2007; 73(4):871-900.

8. Maples WC. Visual factor that significantly impact academic perfomance. Optometry. 2003;74(1): 35-49.

9. Grissom JB. Physical fitness and academic achievement. JEPonline. 2005;8(1):11-25.

10. Eveland-Sayers BM, Farley RS, Fuller DK, Morgan DW, Caputo JL. Physical fitness and academic achievement in elementary school children. J Phys Act Health. 2009;6(1):99-104.

11. Álvarez-Bueno C, Pesce C, Cavero-Redondo I, et al. Academic Achievement and Physical Activity: A Meta-analysis. Pediatrics. 2017;140-6.

12. Asmare B, Taddele $\mathrm{M}$, Berihun $\mathrm{M}$ and Wagnew F. Nutritional status and correlation with academic performance among primary school children, northwest Ethiopia. BMC Res Notes. 2018;11:805.

13. WHO intl. WHO child growth reference 2007. Available at https://www.who.int/ growthref/en. 